\title{
Seyahat Acentelerinin Turist Rehberi Seçim Kriterlerinin Analitik Hiyerarşi Süreci (AHS) Yöntemi ile Değerlendirilmesi
}

\author{
Evaluation of Tourist Guide Selection Criteria for Travel Agencies with Analytic Hierarchy Process (AHP) Method
}

\author{
Burcu ILGAZ YILDIRIM*, Özlem GÜZEL** \\ *Dr. Öğr. Üyesi, Akdeniz Üniversitesi Uygulamalı Bilimler Fakültesi, Dumlupınar Bulvarı, 07058, Kampus, Antalya. \\ E-posta: burcuilgazyildirim@gmail.com \\ ORCID No: 0000-0001-5722-5196 \\ **Doç. Dr., Akdeniz Üniversitesi Turizm Fakültesi, Dumlupınar Bulvarı, 07058, Kampus Antalya. \\ E-posta: ozlemguzel@akdeniz.edu.tr \\ ORCID No: 0000-0003-0081-3530
}

\section{MAKALE BILGILERI \\ Makale işlem bilgileri: \\ Gönderilme tarihi: 20 Şubat 2018 \\ Düzeltme: 7 Haziran 2018 \\ Düzeltme: 20 Haziran 2018 \\ Kabul: 29 Haziran 2018}

Anahtar sözcükler: Turist rehberi, Personel seçimi, Çok kriterli karar verme, AHS.

\section{ARTICLE INFO}

Article history:

Submitted: 20 February 2018

Resubmitted: 7 June 2018

Resubmitted: 20 June 2018

Accepted: 29 June 2018

Key words: Tourist guide, Personnel selection, Multi criteria decision making, AHP.

\section{ÖZ}

Turist rehberleri, turizm sektörünün merkezinde yer alan çok sayıda işletme arasında mesleki bağ kuran ve turistlerin deneyimlerini zenginleştiren turizm çalışanları olarak diğer mesleklerden farklı birtakım özelliklere sahip olmalıdırlar. Cünkü tur programlarının başarısını büyük oranda turist rehberlerinin sahip olduğu donanım, yetenekler ve beceriler etkilemektedir. Bu bağlamda bu araştırmanın amacı; turist rehberlerinin işe alım süreçlerinde önemli olan kriterlerin belirlenerek daha sonra bu kriterlerin önem derecelerinin tespit edilmesidir. Araștırma amacı doğrultusunda öncelikle turist rehberlerinin ișe alım kriterlerinin belirlenmesi için alanyazın taraması ile birlikte uzman görüşleri alınarak kriterler elde edilmiştir. Kriterlerin önem düzeylerinin belirlenmesi için Analitik Hiyerarşi Süreci (AHS) yöntemi kullanılımıştır. Çalışmanın sonucunda turist rehberi seçiminde göz önünde bulundurulan altı adet kriter elde edilmiş ve AHS analizi sonrası bu kriterler arasında önem düzeyi en yüksek olan kriterin mesleki yeterlilik olduğu görülmüștür.

\section{GíRiş}

Antik çağlardan günümüze kadar seyahat endüstrisinin merkezinde olan rehberlik mesleğinin içeriği uluslararası turizm hareketlerinin gelişimine paralel olarak sürekli değişirken turist rehberleri, destinasyonlarda turizm zenginliklerinin değerlendirilmesine katma değer katan ve turistlerin tatil deneyimlerini zenginleştirici işgüçleri haline gelmiştir (Yenen 2002). Çimrin (1995) rehberleri hem turistlerin beklenti ve ter- cihleri hem de destinasyondaki turistik arzın özellikleri ile ilgili deneyim sahibi olduklarından, paket turların yönetiminde tur operatörlerinin ve seyahat acentelerinin en önemli yardımcıları konumunda olan çalışanlar olarak nitelendirmektedir. Leclerc ve Martin (2004) ise turist rehberlerini, kültür aracı ve turist ile yerel halk arasında iletişimi sağlayıcı olarak tanımlamaktadır. Rehberlik mesleği konumu açısından, çok sayıda ve değişik işletme, kuruluş, kurum ve farklı kesimlerle/kişilerle ilişkide bulunan turist 
rehberleri, çoğunlukla turistlere seyahatleri sırasında eşlik eden ve doğrudan iletişim kurabilme imkânına sahip olan turizm çalışanlarıdır (Güzel vd. 2013). İşverenler, turist rehberlerinin turistlerin beklentilerini karşılarken yüksek kaliteli hizmet sunmalarının yanı sıra grubun yönetebilme, güzergâhları ve yolları bilme, turist tatminini sağlama ve kârı artırmalarını da beklemektedir (Cohen 1985). Köroğlu ve Merter (2012), yaptıkları araştırmalarında seyahat acentelerinin, doğru rehberi işe almanın en fazla müşterileri ve işletmeyi etkilediği yönünde tutum geliştirdikleri ve buna göre doğru rehberi işe almanın, müşterileri acenteden tekrar tur satın alması yönünde etkilediğini ortaya koymuşlardır. Bu bağlamda turist rehberlerinin işe alım süreçleri seyahat acenteleri ve tur operatörleri tarafından önemli bir süreç olarak görülmektedir. Doğru işe alım, bir hizmet sektörü olan turizm sektöründe oldukça önemlidir. Turist rehberleri ülkenin temsil ve tanıtım rolünü üstlenmiş, bu bağlamda en önemli hizmeti sunan meslek gruplarından bir tanesidir. Bu noktadan hareketle, alanyazında rehberlerin işe alım kriterlerinin belirlenmemiş olması büyük bir eksiklik yaratmış ve çalışmanın karar aşamasını oluşturmuştur. Daha sonra çalışmanın amacı doğrultusunda ilgili alanyazın taraması ve uzman görüşleri (seyahat acentelerindeki insan kaynakları yöneticileri ve profesyonel turist rehberleri) alınarak çalışmanın konusunu oluşturan kriterler belirlenmiştir. Ortaya çıkan 29 adet alt kriterler gruplandırılmış ve ortaya altı adet ana kriter çıkmıştır. Yapılan analiz sonucunda ise kriterlerin önem sıralaması; mesleki yeterlilik, teknik yeterlilik, fiziksel yeterlilik, sosyal beceri, kişilik özellikleri ve beklenti olarak gerçekleşmiştir. Çalışmanın bulgularının seyahat acentelerine ve bu alanda çalışan akademisyenlere, turist rehberlerinin işe alım süreçlerinde önem arz eden kriterler hususunda fikir sunacağ 1 varsayılmaktadir.

\section{KAVRAMSAL ÇERÇEVE}

\section{Turist Rehberliği}

Türkiye'de 07.06.2012 tarihinde kabul edilen 6326 sayılı Turist Rehberliği Meslek Kanunu'nda turist rehberliği hizmeti ‘seyahat acenteciliği fa- aliyeti niteliğinde olmamak kaydıyla kişi veya grup hâlindeki yerli veya yabancı turistlerin gezi öncesinde seçmiş oldukları dil kullanılarak ülkenin kültür, turizm, tarih, çevre, doğa, sosyal veya benzeri değerleri ile varlıklarının kültür ve turizm politikaları doğrultusunda tanıtılarak gezdirilmesini veya seyahat acenteleri tarafından düzenlenen turların gezi programının seyahat acentesinin yazılı belgelerinde tanımladığı ve tüketiciye satıldığı şekilde yürütülüp acente adına yönetilmesini ifade etmektedir' şeklinde tanımlanmaktadır. Rehberlik mesleğinin tanımında genel kabul görmüş Ap ve Wong'a (2001) göre ise rehberler, sorumluluğu üstlenen liderler, turistlere ziyaret ettikleri yerleri anlamaları için yardımcı olan öğreticiler, ziyaretçilerin tekrar gelmesini sağlayacak şekilde destinasyonu tanıtan/ misafirperverlik sunan amirler ve misafirler için konforlu bir çevre sağlayan ev sahipleridir. Turist rehberlerinin sahip oldukları bilgi, anlatma kabiliyeti ve verdikleri rehberlik hizmeti turistlerin ziyaretini turdan deneyime aktarmaktadır (Zhang ve Chow 2004).

Bir turist rehberi, "dışa dönük olma, misafirperverlik, konuşma ve espri yeteneği, insan sevgisi ve tutku, hoşgörülü ve dürüst olma, yenilikleri izleyebilme, cana yakın olma, bilgi ve donanım, yabancı dil bilgisi, genel kültür ve ilk yardım bilgisi" gibi unsurlara sahip olmalıdır (Değirmencioğlu 1997; Dahles, 2002; Wong ve Lee 2012). Profesyonel Turist Rehberi Ulusal Meslek Standardına göre turist rehberinin tutum ve davranış boyutları (2010); disiplinli, yenilikleri uygulayıcı, araştırmacı, bakımlı, sorumlu, iş bitirici ve çevreye duyarlı olmak, ayrımcilık yapmamak, etkili ve güzel konuşmak, güler yüzlü ve nazik davranmak, soğukkanlı olmak ve sorunlara çözüm üretebilmek, meslek ahlakına sahip olmaktır.

Huang' in (2010) rehberlerin özellikleri üzerine yaptığı araştırmasında rehberlerin sahip olması gereken temel özellikler ve unsurlar şu şekilde sıralanmıştır; sorumluluk duygusu, arkadaş canlısı olma, iş ahlakına sahip olma, dakiklik, zaman yönetimi, kibar yaklaşım, dürüstlük ve güvenilir olma, iyi karaktere sahip olma, destinasyon geçmişi hakkında bilgi, yardımseverlik, prezantabl görünüm, fiziki sağlık, ilgili olma, destinasyon 
kültürü bilgisi, dil yeterliliği, turistin güvenliğini sağlama, şikayetleri çözümleme, diğer kültürleri anlama, karışıklık ve problemleri çözebilme, erişilebilir olma, empati kurma, yorumlama yeteneği, güvenilir dükkanlara yöneltme ve turistlerin psikolojik ihtiyaçlarını karşılama. Huang ve diğerlerinin (2010) yaptığı çalışmada turist rehberi performansı özellikleri profesyonel yetenek (destinasyon kültürü, çekicilik ve yerel yaşam bilgisi vb.), kişiler arası yetenek ve organizasyon (şikayetleri yönetme, zaman yönetimi vb.), empati (turist psikolojisini anlama, tutku vb.) ve problem çözme olarak boyutlandırılmıştır. Alanyazında kültürlerarası etkileşimin olduğu turizm sektöründe rehberlerin iletişim becerileri ve tur performansı ilişkisinin önemini vurgulayan araştırmalara rastlanmaktadır (Dawood vd. 2016).

$\mathrm{Bu}$ bağlamda alanyazında rehberlere yönelik belirtilen turum, davranış, özellikler, meslek profili ve kalifikasyon içerikleri göz önüne alındığında seyahat acenteleri ve tur operatörlerinin işe alım süreçleri bağlamında hangi kriterlerin ön plana çıktığının keşfedilmesi hususunda bu çalışmanın turist rehberlerinin personel seçim süreçleri hususunda geniş bir bilgi sağlayacağ sayılmaktadır.

\section{Personel Seçimi ve Çok Kriterli Karar Verme}

İşletmelerde personel seçimi, işletmenin geleceğine ilişkin birçok durumu negatif veya pozitif yönde etkileyebilmektedir. Bu nedenle personel seçimi üzerine birçok bilimsel çalışma gerçekleştirilmiştir. Doğru personelin seçimi birçok aşama ve teknik gerektirmektedir. İşletmeler doğru personel seçiminde, yapılacak işin niteliğini de göz önüne alarak adayları değerlendirmeye almaktadır. İşletmeler personel seçimi gerçekleştirirken çeşitli teknikler kullanırlar. Bunlardan en sık karşılaşılanları öngörüşme, çeşitli testler (bilgi ölçek veya psikoteknik testler), yüz yüze görüşme (mülakat) gibi tekniklerdir. İş başvurusunda bulunan adaylar bu süreçlerden geçirildikten sonra adayın işe yerleştirilmesi aşamasına geçilmektedir.

Bu süreçte önemli olan husus boş pozisyona işgören almak değil, doğru işe doğru kişiyi istihdam edebilmektir (Sabuncuoğlu 2009:78). Seçim sürecinde etkinlik, işgörenin işe uyumu ve çal1şanlara uyumu olarak iki boyutta ele alınmal1dır. Seçim sürecinde yanlış personelin istihdam edilmesi, işletmeye hukuki ve finansal riskleri de beraberinde getirir. Bu iki uyuma dikkat edilirse doğru bir işe alım süreci gerçekleşmiş olacaktır (Werther ve Davis 1993: 230).

Turizm sektörü, hizmet sektörünün bir parçası olması bakımından hizmet üreten insan kaynaklarına yönelmektedir. Bu bağlamda sektörün rekabet edilebilirliği konusunda doğru insan kaynakları seçimi büyük önem taşır (Akova vd. 2007: 276). Bu bağlamda, turist rehberleri, turistlerin seyahat deneyimleri sırasında büyük bir etkiye sahiptir. Rehberlerin doğru kriterlerle, doğru bir seçim yapılarak işe alımının yapılmış olması gerek acentenin rekabet edebilirliği açısından gerekse turistlerin memnuniyet ve motivasyonları açısından belirleyici rol üstlenmektedir.

Alanyazında çok sayıda çok kriterli karar verme yöntemi bulunmaktadır. Kullanılan her yöntemin kendine ait süreçleri bulunur. Bu yöntemlerin bazıları; AHS, EKLEKTRE, TOPSIS, MOORA, PROMETHEE yöntemleridir. Bu yöntemler problemin çözümü sırasında farklı şekillerde ele alınmakta ve aşağıdaki gibi sıralanmaktadır (Bölat ve Kuzucu 2006: 115):

Karar vericiden açıkça bilgi istemeyen yöntemler,

Karar vericiden başlangıçta bilgi isteyen yöntemler,

Karar vericiden karar esnasında ardışık olarak bilgi isteyen yöntemler,

- Karar vericiden bilgiyi sonradan isteyen yöntemler.

\section{ALANYAZIN TARAMASI}

Alanyazında işletmelerde personel seçim kriterlerinin AHS yöntemi ile belirlenmesine ilişkin birçok çalışma yer almaktadır. Ancak turist rehberlerinin personel seçim süreci üzerine yapılmış tek bir yayına rastlanmıştır. Köroğlu ve Merter (2012) tarafından yapılan bir çalışmada, seyahat acentelerine turist rehberi işe alım süreçleri ile ilgili anket uygulayarak işletmelerin işe alırken dikkat ettikleri hususlar ortaya konulmaya ça- 
lışılmıştır. Çalışmanın örneklemini İstanbul'da faaliyet gösteren seyahat acenteleri oluşturmaktadır. Çalışmanın sonucuna göre, işe alım süreçlerinde en fazla tercih ettikleri yöntem, çalışan ve tanıdık tavsiyelerinin dikkate alınmasıdır. Bir diğer sonuç ise çalışanların seçiminde sektör tecrübelerinin dikkate alınıyor olmasıdır. Black ve King'in (2002) ve Weiler ve Ham'in (2002) rehberler üzerine yapmış oldukları çalışmalarında, rehberlerin mesleki altyapı ve bilgi donanımlarının önemli bir unsur olduğunu vurgulamışlardır. Demirkol ve Ekmekçi (2005), rehberlerin mesleki bilgi yeterliliğinin önemi üzerinde dururken, rehberlerin yabancı dile hâkimiyetlerinin önemini vurgulamaktadır. Akova vd. (2007) seyahat acentelerinde işgören bulma ve seçme yöntemlerine ilişkin bir araştırma yapmıştır. Özdemir ve Akpınar (2002) ise turizm sektöründe işgörenlerin işe alım süreçlerinde referansın önemini vurgulamıştır. Şimşek vd. (2014) yaptıkları çalışmada turizm sektöründe personel seçimini bulanık AHS yöntemi ile incelemiştir. Yine Urosevic vd. (2017), araştırmalarında Swara ve Waspas yöntemlerini kullanarak personel seçimine yönelik en önemli kriterin liderlik kriteri olduğu sonucuna ulaşmışlardır. Matin vd. (2015) personel seçimi ile ilgili çalışmasında bulanık TOPSİs yöntemi kullanmış ve çalışmanın sonucunda personel seçimindeki en önemli ilk üç kriterin karar verme, ekip çalışması ve analitik düşünme olduğu sonucuna ulaşmıştır. Stanujkic vd. (2012) ARAS ve SWARA yöntemleri ile yaptıkları araştırma sonucuna göre, rehberlerin işe alım süreçlerindekien önemli kriter mesleki deneyim ve eğitim olmuştur. Zhang ve Liu (2011) çok kriterli karar verme metodu kullanarak personel seçim kriterlerinin ağırlıklarını belirlemiştir. Diğer çalışmalarla benzer şekilde mesleki tecrübenin en önemli kriter olduğu sonucuna ulaşmıştır. Ji, Zang ve Wang (2016), çalışmalarında en önemli iki kriterin sözlü iletişim becerisi ve mesleki tecrübeler olduğunu belirlemiştir. Çok kriterli karar verme yöntemleri, personel seçiminde kullanılması önerilen ve alanyazında sık çalışılan bir yöntemdir. Çok kriterli karar verme yöntemleri nitel verileri nicel verilere dönüștürmesi fırsatlarından bir tanesidir.

\section{ARAŞTIRMANIN AMACI VE YÖNTEMI}

Çalışmanın konusunu oluşturan kriterlerin belirlenebilmesi için derinlemesine bir alanyazın taramasının ardından sektörde aktif olarak çalışan dört turist rehberi ve iki acente yöneticisi ile görüşme gerçekleştirilmiştir. Görüşme yapılan kişilere "turist rehberlerinin sahip olması gereken ve işe alım sürecinde deneyimlerinden yola çıkarak önem arz eden unsurların detaylı bir şekilde açıklanması" istenmiştir. Görüşmelerin belli bir ölçüde tutarlılık içerisinde gerçekleşmesi için görüşmeler sırasında yarı yapılandırılmış görüşme formları kullanılmıştır. Yapılan bu görüşmeler ve alanyazın taramasının ardından kriterler, ana kriterler ve ana kriterlerin açıklandığı alt kriterler belirlenmiştir. Bu kriterlerin önem dereceleri Analitik Hiyerarşi Süreci (AHS) yöntemi kullanılarak belirlenmiştir. AHS yöntemi 1970'li yıllarda Prof. Saaty tarafından geliştirilmiştir. Bu yöntem; karar vericilere karmaşık bir problemi, hiyerarşik bir yapıda modelleme olanağı sağlar (Forman ve Selly 2011: 42). AHS, hiyerarşinin gerçekleştirilmesi, ikili karşılaştırmalar, önem seviyelerinin belirlenmesi, tutarlılık ve nihai karar aşamaları gibi adımları içermektedir.

\section{AHS Yönteminin Aşamaları}

\section{Hiyerarşinin Gerçekleştirilmesi}

AHS'nin ilk adımı, karar probleminin daha kolay anlaşılabilmesi ve değerlendirilebilmesi için hiyerarşik bir düzende alt problemlere ayrıştırılmasıdır (Kuruüzüm ve Atsan 2001: 86). Problemin örnek hiyerarşik yapısı Şekil 1'de görülmektedir. Bu yapı kriterlerle adaylar arasındaki ilişkinin model üzerinde gösterimidir.

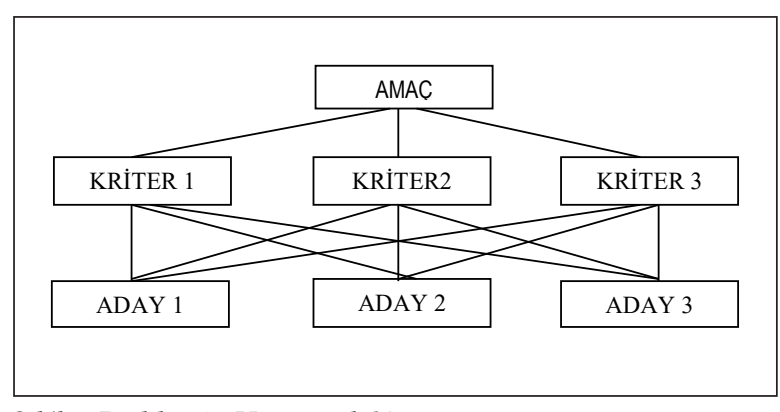

Şekil 1. Problemin Hiyerarşik Yapısı 


\section{Íkili Karşılaştırma Matrisi}

$\mathrm{Bu}$ aşamada ana kriterlerin ve alt kriterlerin her biri, karar verici tarafından $X$ kriterinin $Y$ kriterine göre önem düzeyi göz önünde bulundurularak puanlanmaktadır. Puanlama, seyahat acentesinin insan kaynakları yöneticisi olarak görev yapan üç uzmanın görüşlerinin ortalaması alınarak gerçekleştirilmiştir. Puanlamada 1-9 puanlı tercih ölçeğinden faydalanılmıştır. AHS değerlendirme ölçeğine ilişkin değerler Tablo 1'de gösterilmektedir.

Tablo 2'de görülen matrise göre wi/wj terimi, i kriterinin j kriterine göre ne kadar önemli olduğunu göstermektedir. Örneğin; kriterin önem değeri 5 ise i kriteri j kriterine göre daha kuvvetli düzeyde önemli, aynı zamanda j kriteri i kriterine göre 1/5 düzeyinde önemli olmaktadır (Vargas 1990: 4).

\section{Kriterlerin Göreli Önem Matrisi}

Kriterler için ikili karşılaştırma matrisi oluşturduktan sonra önem matrisi oluşturulmaktadır. Her kriterin sütun toplamına kriter değeri bölünerek elde edilmektedir. İlgili sütunların ortalaması ile elde edilen önem düzeyi, nihai sıralamay1 göstermektedir. Kriterlerin alt kriterlerine ait nihai sıralama ise her bir kriterin önem düzeyi ile alt kriterlerin önem düzeyinin çarpılması ile elde edilmektedir.

\section{Tutarlılık}

Analiz sonucunda elde edilen nihai kararın tutarlılığ 1 önemlidir. Bu, rasyonel düşünmenin bir önkoşulu olarak kabul edilir. Tutarlık oranını ölçmek için Saaty tarafından önerilen tutarlılık oranı kullanılmaktadır. Tutarlık oranlarını gösteren başka çalışmalarda yapılmıştır (Kuruüzüm ve Atsan 2001: 92). Bu çalışmada Saaty'nin belir-

Tablo 1. AHS Değerlendirme Ölçeği

\begin{tabular}{lll}
\hline Önem & Tanım & Açıklama \\
\hline 1 & Eşit Derecede Önemli & İki faktör aynı derecede önem taşır \\
\hline 3 & Biraz daha fazla önemli & Biri diğerine göre biraz daha fazla önemlidir \\
\hline 5 & Oldukça önemli & Biri diğerine göre oldukça önem taşır \\
\hline 7 & Çok daha önemli & Biri diğerine göre çok daha fazla önem taşır \\
\hline $2,4,6,8$ & Kesinlikle daha önemli & Biri diğerine göre kesinlikle daha fazla önem taşır \\
\hline
\end{tabular}

Kaynak: Saaty1980: 54.

Tablo 2. Kriterler İçin İkili Karşılaştırma Matrisi

\begin{tabular}{lllr} 
& Kriter 1 & Kriter 2 & Kriter..n \\
\hline Kriter 1 & w1/w1 & w1/w2 & w1/wn \\
\hline Kriter 2 & w2/w1 & w2/w2 & w2/wn \\
\hline Kriter..n & wn/w1 & wn/w2 & wn/wn \\
\hline
\end{tabular}

Kaynak: Saaty 1990: 4.

Tablo 3.Rassallık Göstergesi

\begin{tabular}{|c|c|c|c|c|c|c|c|c|c|c|c|c|c|c|}
\hline$N$ & 1 & 2 & 3 & 4 & 5 & 6 & 7 & 8 & 9 & 10 & 11 & 12 & 13 & 14 \\
\hline Rassallık Göstergesi & 0 & 0 & 0,58 & 0,9 & 1,12 & 1,24 & 1,32 & 1,41 & 1,45 & 1,49 & 1,51 & 1,48 & 1,56 & $1,57 \quad 1,59$ \\
\hline
\end{tabular}

Kaynak: Kwiesielewicz ve Uden2004: 31 
lemiş olduğu oranlar esas alınmıştır. İlgili değerlere ilişki Tablo 3'te yer almaktadır.

Tutarlılık oranı aşağıdaki şekilde formüle edilmektedir.

$$
\mathrm{CR}=\frac{\mathrm{CI} \text { (Tutarlılık Göstergesi) }}{\mathrm{RI} \text { (Rassallık Göstergesi) }}
$$

Elde edilen tutarlılık değerinin $0,1^{\prime}$ den küçük olması gerekmektedir. Aksi halde karar vericinin yapmış olduğu değerlendirmeyi yeniden gözden geçirmesi gerekir.

\section{BULGULAR}

\section{Kriterlerin Belirlenmesi}

Kriterler belirlenirken amaçlı örneklem dahilinde Avrupa ve Rus pazarında Türkiye'ye en çok turist getiren tur operatörlerinin karşılayıcı acentelerinin tur operasyon müdürleri ve "sektörde eylemli olarak çalışan ve en az on yıl rehberlik tecrübesi olan" rehberler ile görüşme yapılmıştır. Bu iki acente kümülatif olarak en çok turist getiren acenteler iken en çok yerel-Anadolu turları yapan dolayısıyla turist rehberlerini seçerken belli başlı unsurları göz önünde bulunduran ve rehberlerin bilgi-donanım kalitesine özen gösteren işletmelerdir. Bu görüşmelerde; "Acentenize istihdam edeceğiniz turist rehberinde bulunmasi gereken özellikleri detaylı olarak anlatır misınız?" sorusu sorulmuştur. Rehberlere "Acentelerin istihdam edeceği turist rehberinde bulunmasını istediği özellikleri detaylı olarak anlatır mısınız?" ve "Size göre rehberlerin sahip olması gereken özellikleri detaylı olarak anlatır mısınız?" soruları sorulmuştur. Yapılan görüşme sonucunda altı ana kriter, 29 alt kriter elde edilmiştir.

\section{AHS Yöntemi ile Turist Rehberi Seçim Kriterlerinin Değerlendirilmesi}

Elde edilen kriterlerin önem dereceleri AHS yöntemi ile değerlendirilmiştir. Yapılan görüşmeler ve alanyazın araştırması sonucunda altı adet ana kriter ve 29 adet alt kriter belirlenmiştir. Yönteme ait aşamalar aşağıda sırasıyla verilmiştir.

\section{İkili Karşılaştırma Matrisi}

İkili karşılaştırma matrisleri öncelikle ana kriter arasında daha sonra bu ana kriterlerin alt kriterleri arasında gerçekleştirilmiştir. Kriterlere ve alt kriterlere ait karşılaştırma matrisleri oluşturulmuştur. Bu matriste yer alan altı adet ana kriter, bir seyahat acentesinin insan kaynakları yöneticisi olarak görev yapan iki uzman tarafından değerlendirilmesi ile elde edilmiştir. Önem skalasinda yer alan toplam 15 adet değerlendirme tabloya aktarılmış ve tablonun geri kalanı ise 1/wn olarak hesaplanmıştır.

\section{Kriterlerin Göreli Önem Matrisi ve Tutarlılık Değerleri}

Kriterler ve alt kriterleri içeren her bir tablonun önem matrisi oluşturulmuştur. Her kriterin sütun toplamına kriter değeri bölünerek elde edilen değerlerin sütun ortalamaları alınarak önem düzeyi belirlenmiştir. Daha sonra rassallık göstergesinden yararlanılarak tutarlılık düzeyleri (CR) ölçülmüsştür. Tutarlılık düzeyleri 0,10 değerinden düşük olduğu için uzman tarafından elde edilen görüş̧ler tutarlıdır denilebilir. Çalışmanın kriterlerine ilişkin önem düzeyleri, nihai siralama ve tutarlılık düzeyleri Tablo 5'te yer almaktadır. Önem düzeyi en yüksek olan kriter en önemli kriter olarak adlandırılmaktadır. Nihai s1ralamanın sonucuna göre en önemli olan kriterin mesleki yeterlilik kriteri olduğu görülmektedir. İkinci derecede öneme sahip kriter teknik yeterlilik, diğer kriterler sırasıyla; sosyal beceri, kişilik özelliği, beklenti ve fiziksel yeterlilik kriterleridir. Matrislerin tutarlılık oranı 0,10'un altında olduğu için uzman görüşünün matrisi tutarlı oluşturduğu söylenebilir. 
Tablo 5. Ana ve Alt Kriterlere Ait Önem Düzeyi, Tutarlılık Düzeyi ve Nihai Sıralama

\begin{tabular}{|c|c|c|}
\hline Kriterler & Önem düzeyi & Siralama \\
\hline Mesleki Yeterlilik & 0,424442 & 1 \\
\hline Teknik Yeterlilik & 0,281997 & 2 \\
\hline Fiziksel Yeterlilik & 0,032266 & 6 \\
\hline Sosyal Beceri & 0,129449 & 3 \\
\hline Kişilik Özellikleri & 0,086642 & 4 \\
\hline Beklenti & 0,045205 & 5 \\
\hline \multicolumn{3}{|c|}{ Tutarlılık oranı: 0,069226 $(C R<0,1)$} \\
\hline Mesleki Yeterlilik Kriteri & Önem düzeyi & Siralama \\
\hline Genel Kültür & 0,110298 & 4 \\
\hline Adet ve Gelenek & 0,112533 & 3 \\
\hline Destinasyonu Tanıma & 0,248839 & 2 \\
\hline Uzmanlaşma & 0,041485 & 5 \\
\hline Tecrübe Yılı & 0,450354 & 1 \\
\hline Referans & 0,036490 & 6 \\
\hline \multicolumn{3}{|c|}{ Tutarlılık oranı: $0,074209(C R<0,1)$} \\
\hline Teknik Yeterlilik & Önem Düzeyi & Siralama \\
\hline Dil bilgisi & 0,677649 & 1 \\
\hline İlkyardım bilgisi & 0,050763 & 4 \\
\hline Etkin teknoloji kullanımı & 0,145242 & 2 \\
\hline Yol bilgisi & 0,126346 & 3 \\
\hline \multicolumn{3}{|c|}{ Tutarlılık oranı: 0,042606 $(C R<0,1)$} \\
\hline Fiziksel Yeterlilik & Önem Düzeyi & Siralama \\
\hline Fiziksel Dayanıklılık & 0,647947 & 1 \\
\hline Prezantabl Görünüm & 0,122182 & 3 \\
\hline Enerjik Olma & 0,229871 & 2 \\
\hline \multicolumn{3}{|c|}{ Tutarlılık oranı: 0,003187 $(C R<0,1)$} \\
\hline Sosyal Beceri & Önem Düzeyi & Siralama \\
\hline Kişilerarası ilişki & 0,237502 & 2 \\
\hline Güleryüzlü Olma & 0,039191 & 6 \\
\hline Yardımseverlik ve İlgi & 0,130497 & 3 \\
\hline Mizah Yeteneği & 0,103246 & 4 \\
\hline Takım Çalışması ve Uyum & 0,066581 & 5 \\
\hline Etkili Konuşma ve Diksiyon & 0,422982 & 1 \\
\hline
\end{tabular}


Tablo 5. Ana ve Alt Kriterlere Ait Önem Düzeyi, Tutarlılık Düzeyi ve Nihai Sıralama (Devam)

\begin{tabular}{|c|c|c|}
\hline Kişilik ÖzellikleriÖnem Düzeyi & Siralama & \\
\hline Güvenilir Olma & 0,025359 & 7 \\
\hline Empati Kurabilme & 0,245612 & 3 \\
\hline Problem Çözme ve Yönetebilme & 0,285432 & 1 \\
\hline Liderlik & 0,265561 & 2 \\
\hline Sabırlı Olma & 0,037371 & 5 \\
\hline Özgüven & 0,104210 & 4 \\
\hline Ahlak & 0,036455 & 6 \\
\hline \multicolumn{3}{|c|}{ Tutarlılık oranı: 0,009113 $(\mathrm{CR}<0,1)$} \\
\hline Beklenti & Önem Düzeyi & Siralama \\
\hline Sosyal güvence & 0,079644 & 3 \\
\hline Maaş & 0,655545 & 1 \\
\hline Komisyon & 0,264822 & 2 \\
\hline \multicolumn{3}{|c|}{ Tutarlılık oranı: $0,084257(C R<0,1)$} \\
\hline \multicolumn{3}{|l|}{ Alt Kriterlerin Sıralaması } \\
\hline Alt Kriterler & Önem Düzeyi & Siralama \\
\hline Tecrübe yılı & 0,191149042 & 1 \\
\hline Dil bilgisi & 0,191094614 & 2 \\
\hline Destinasyonu tanıma & 0,105617936 & 3 \\
\hline Etkili konuşma ve diksiyon & 0,054754649 & 4 \\
\hline Adet ve gelenek & 0,047763944 & 5 \\
\hline Genel kültür & 0,04681528 & 6 \\
\hline Teknoloji k. & 0,040957709 & 7 \\
\hline Yol bilgisi & 0,035629151 & 8 \\
\hline Kişilerarası ilişki & 0,030744456 & 9 \\
\hline Maaş & 0,02963368 & 10 \\
\hline Problem çözme ve yönetebilme & 0,024730317 & 11 \\
\hline Liderlik & 0,023008668 & 12 \\
\hline Empati kurabilme & 0,02128028 & 13 \\
\hline Fiziksel dayanıklılık & 0,020906506 & 14 \\
\hline Uzmanlaşma & 0,017608034 & 15 \\
\hline Yardımseverlik ve ilgi & 0,016892723 & 16 \\
\hline Referans & 0,015487967 & 17 \\
\hline İlkyardım bilgisi & 0,014315071 & 18 \\
\hline Mizah yeteneği & 0,013365081 & 19 \\
\hline
\end{tabular}


Tablo 5. Ana ve Alt Kriterlere Ait Önem Düzeyi, Tutarlılık Düzeyi ve Nihai Sıralama (Devam)

\begin{tabular}{llr}
\hline Komisyon & 0,011970701 & 20 \\
Özgüven & 0,009028918 & 21 \\
Takım çalışması ve uyum & 0,008618847 & 22 \\
Enerjik olma & 0,007416971 & 23 \\
Güleryüzlülük & 0,005073301 & 24 \\
Prezantabl görünüm & 0,003942295 & 25 \\
Sosyal güvence & 0,003600265 & 26 \\
Sabırlı olma & 0,003237888 & 27 \\
Ahlak & 0,003158554 & 28 \\
Güvenilir olma & 0,002197153 & 29 \\
\hline
\end{tabular}

Tablo 5'te nihai sıralamanın sonucuna göre en önemli olan kriterin mesleki yeterlilik kriteri olduğu görülmektedir. İkinci derecede öneme sahip kriter teknik yeterlilik, diğer kriterler sırasıyla; sosyal beceri, kişilik özelliği, beklenti ve fiziksel yeterlilik kriterleridir. Mesleki yeterlilik kriterinin önem düzeyi en yüksek kriteri, tecrübe yılı olarak ortaya çıkmıştır. Ana kriterlerden en önemli ikinci kriter olan teknik yeterlilik kriterinin en önemli alt kriteri, dil bilgisi olmuştur. Önem sıralamasında üçüncü sırada yer alan fiziksel yeterliliğin en önemli kriteri, dayanıklılık kriteri olarak belirlenmiştir. Sosyal beceri kriterinin önem düzeyi en yüksek alt kriteri, etkili konuşma ve diksiyondur. Kişilik özellikleri ana kriterinin alt kriteri açısından önem düzeyi sıralamasına bakıldığında en yüksek önem düzeyine sahip alt kriterin, problem çözme ve yönetebilme olduğu görülmüştür. Son kriter olan beklenti kriterinin önem düzeyi en yüksek alt kriterine bakıldığında; maaş kriteri olduğu görülmüştür.

\section{SONUÇ}

Turist rehberlerinin işe alım süreçlerinde önem arz eden kriterlerin ve önem derecelerinin belirlenmesi amacıyla gerçekleştirilen bu araştırmada öncelikli olarak nitel aşamada altı önemli kriter (mesleki yeterlilik, teknik yeterlilik, fiziksel yeterlilik, sosyal beceri, kişilik özellikleri ve beklenti) belirlenmiştir. Bu kriterler ve alt kriterleri göz önüne alındığında mesleğin kendine has içeriği itibarıyla birçok meslekten farklı olarak turist rehberinden çoklu donanım ve özelliklere sahip olması beklentisinin var olduğu görülmektedir.

Elde edilen kriterlerin ortaya çıkarılması sonrasinda seyahat acentesi ve tur operatörlerinin hangi kriterlere önem atfettikleri AHS yöntemi ile keşfedilmiştir. Elde edilen kriterler önem derecesine göre; "mesleki yeterlilik, teknik yeterlilik, sosyal beceri, kişilik özellikleri, beklenti ve fiziksel yeterlilik" olarak sıralanmıştır. Şimşek vd. (2014) yapmış oldukları çalışmalarında mesleki yeterlilik kriterinin, en önemli kriter olduğu sonucuna ulaşmışlardır. Ji vd. (2016) en önemli ikinci kriteri mesleki tecrübe olarak tespit etmiştir. Zhang ve Liu (2011) çalışmada bulunan sonuçla benzer olarak en önemli kriteri mesleki tecrübe olarak elde etmiştir. Stanujkic vd. (2012) ARAS yöntemi ile yapmış oldukları çalışmalarında mesleki yeterlilik ve eğitimin en önemli kriterler olduğu sonucuna ulaşmıştır. Mesleki yeterlilik kriterinin en önemli özellik olarak ortaya çıkması rehberlerin mesleki donanımlarına verilen önemi göstermektedir. Mesleki donanım bağlaminda öneme göre ise "tecrübe yılı, destinasyonu tanıma, adet ve gelenek, genel kültür, uzmanlaşma ve referans" kriterleri sıralanmıştır. Yıl olarak rehberin sektörde kalma süresi arttıkça rehberin bilgi ve tecrübe birikimi ile birlikte acentenin tur hizmet kalitesi de artacaktır. Rehberlerin sahip olduğu referanslar (eski çalıştığı kurum, eğitici ve turist referansları) rehbere duyulan güveni 
artırmaktadır. Uzmanlaşma ise özel ilgi turizmi bağlamında aranan bir koşul haline gelmiştir. Çünkü belirli konulara ilgi duyan turistler için düzenlenen geziler özel ilgi turizmi kapsamında değerlendirilirken, turizm tüketicisi profilinde var olan değişimlerde bu geziler için konunun uzmanı rehberlerin seçilmesini zorunlu hale getirmektedir (Köroğlu ve Güdübulak 2017). Bu boyut bağlamında turist rehberlerinin henüz eğitim-öğretim dönemlerinde uygulamaya dönük olarak yetiştirilmesi ve hem tecrübe hem de uzmanlıklarının artırılması önemli bir husustur. Bu bağlamda turist rehberleri Türkiye'nin iç ve diş siyasetinden sosyal ve etnik yapısına kadar çok değişik yönlerini, zenginliklerini doğru bir şekilde anlatmak ve görsel kılmak gibi çok önemli görevler üstlenmektedirler (Gündüz 2002). Demirkol ve Ekmekçi (2005) mesleki bilgi yeterliliğinin önemi üzerinde dururken, rehberlerin yabancı dile hâkimiyetlerinin yanı sıra turiste aktaracak bilgilerinin de olması gerekliliğini ve gezdirdiği yerlerin kültürü, tarihi ve coğrafi, beşeri, iklimsel yapısı hakkında insanları aydınlatabilmesi gerekliliğinin öneminden bahsetmektedir. Bu bağlamda bu araştırmada da en önemli kriter olarak mesleki yeterliliğin ortaya çıkması, acentelerin de rehberlerden beklentilerinin bu yönde olduğunu göstermektedir. Bu kriterler önem derecesine göre; tecrübe yılı, destinasyonu tanıma, adet ve gelenek, genel kültür, uzmanlaşma ve referans olarak sıralanmaktadır. Huang ve diğerlerinin (2010) çalışmasında profesyonel yeterlilik bağlamında destinasyon kültürü, çekicilik ve yerel halk bilgisinin, turist tatmini üzerinde önemli özellikler olduğu ortaya çıkmıştır. Köroğlu ve Merter (2012) ve Özdemir ve Akpınar da (2002) çalışmalarında işe alımda referansın dikkate alınan bir kriter olduğunu vurgulamışlardır. Aynı zamanda mesleki yeterlilik boyutunun işe alım sürecinde önemli bir kriter olduğu sonucu bazı çalışmalarla (Örücü 2002; Özdemir ve Akpınar 2002; Köroğlu ve Merter 2012) benzerlik göstermiştir. Bu noktada rehberlerin eğitim dönemlerinde altyapılarını doldurabilmeleri ve kendilerini yetiştirmeleri önemlidir ve alanyazında da bunu destekleyen çalışmalar keşfedilmiştir (Black ve King 2002; Weiler ve Ham 2002; Huang 2010; Huang vd. 2010). Teknik yeterlilik boyutu analiz sonucunda önemli olarak görülen ikinci boyut olarak ortaya çıkmıştır. Bu boyut altında ise önem sırasına göre dil bilgisi, aktif teknoloji kullanımı ve yol bilgisi ile ilkyardım bilgisi kriterleri yer almaktadır. Acenteler ve tur operatörleri için rehberin sektörde sahip olduğu yabancı dil bilgisi, diğer boyutları da destekleyen bir unsurdur. Bu nedenle rehberlerin yabancı dil bilgi düzeylerinin yanı sıra nadir diller sınıfından dil bilgisine sahip olması sektörde iyi bir yer edinmesine olanak tanımaktadır. Huang'ın (2010) ve Hiore'nin (2010) çalışmasında da dil bilgisi rehberlerin sahip olması gereken en önemli özellik olarak ortaya çıkmıştır. Özellikle kültür turlarına katılan rehberler için yol bilgisi oldukça önemlidir. Yalnızca kaptan ve rehberle yapılan bu uzun yolculuklarda tecrübe kolaylaştırıcı unsurdur.

Sosyal beceri boyutu önem sırasına göre üçüncü boyut olarak ortaya çıkmıştır. Sosyal beceri boyutu içinde yer alan kriterler önem sırasına göre şu şekilde sıralanmıştır; etkili konuşma ve diksiyon, kişiler arası ilişki, yardımseverlik ve ilgi, mizah yeteneği, takım çalışması ve uyum, güler yüzlü olma. Dawood vd. (2016), rehberlerin iletişim becerilerine yönelik yaptıkları araştırmalarında rehberlerin sözlü sunum yeteneklerinin (dilbilgisi, konuşma hızı, cümle seçimi gibi) ve turiste yaklaşım, arkadaş canlısı olma gibi sözlü olmayan iletişim becerilerinin geliştirilmesi gerektiği ortaya çıkmıştır. Akova da (2007)çalışmasında diksiyonun en önemli unsurlardan biri olduğu sonucuna ulaşmıştır. Hiore'nin (2010) yaptığ çalışmada arkadaş canlısı, ilgili ve kibar olmanın rehberlikten beklenen önemli özellikler olduğu ortaya çıkmıştır. Bu bağlamda Balta'nın (2017) vurguladığ 1 gibi bir turist rehberinin, zor insanlarla etkili iletişim kurabilmesi, onların davranışlarını anlayabilmesi, öfke kontrol yöntemlerini uygulayabilmesi ve kendini bu konularda geliştirebilmesi gerekmektedir. Ahipaşaoğlu da (1997) bir rehberin ilgi alanına giren disiplinleri sosyal ilişkiler ve yönetim açısından insan ilişkileri, görgü kuralları, psikoloji, sosyoloji, protokol, animasyon olarak sinıflandırmaktadır. Matin vd. (2005) ise TOPSís yöntemi kullanarak yapmış olduğu çalışmasında benzer olarak takım çalışmasının önemli olduğu sonucunu vurgulamiştır. 
Kişilik özelliği boyutu dördüncü önemli kriter olarak ortaya çıkmıştır. Bu çalışmada kişilik boyutu içinde yer alan kriterler önem sırasına göre problem çözme ve yönetebilme, liderlik, empati kurabilme, özgüven, sabırlı olma, ahlaklı ve güvenilir olma olarak sıralanmıştır. Balta (2017) turist rehberliği mesleğini seçen kişilerin bir takım farklı kişilik örüntülerine sahip olması gerektiğini, ancak bu özelliklerin belirlenmesine yönelik çalışmaların yetersiz olduğunu belirtmektedir. Hiore'nin (2010) yaptığ 1 araştırmada da liderlik, turistlerin rehberden beklediği önemli bir özellik olarak ortaya çıkmıştır. Nitekim Urosevic vd. (2007), personel seçimine yönelik yapmış oldukları çalışmalarında liderlik kriterinin önemini vurgulamıştır.

Beklenti boyutu beşinci önemli boyut olarak ortaya çıkmıştır. Bu boyut içinde ise sırasıyla maaş, komisyon ve sosyal güvence kriterleri yer almaktadır. Turist rehberlerinin en önemli mesleki sorunlarından biri maaş sorunudur. Acentelerin maaş konusuna ve sonrasında komisyona verdikleri önemden de bu durum anlaşılmaktadır.

Son olarak fiziksel yeterlilik kriteri altıncı kriter olarak önem sırasında yer almıştır. Bu boyut içinde yer alan kriterler ise önem sırasına göre fiziksel dayanıklılık, enerjik olma ve prezantabl görüntüdür. Bu kriterler, rehbere turistlerin gözünde saygınlık kazandıracak ve şirkete yönelik temsiliyet algısı yaratacak en önemli unsurlardır.

Tüm kriterlerin önem düzey sıralaması gerçekleştirildiğinde önemli bulgular elde edilmiştir. Kriterler ana kriterler göz önünde bulundurulmadan önem sirasına koyulduğunda ise sıralama; tecrübe yılı, dil bilgisi, destinasyonu tanıma, konuşma ve diksiyon, adet ve gelenek bilgisi, genel kültür, etkin teknoloji kullanımı, yol bilgisi, kişiler arası ilişki kurma becerisi, maaş beklentisi, problem çözme ve yönetebilme, liderlik, empati kurabilme, fiziksel dayanıklılık, uzmanlaşma, yardımseverlik ve ilgi, etkili referanslar, ilk yardım bilgisi, mizah yeteneği, komisyon, özgüven, takım çalışması ve uyum, enerjik olma, güler yüzlü olma, prezantabl görünüm, sosyal güvence, sabırlı olma, ahlaklı ve güvenilir olma olarak ortaya çıkmıştır. Bu kriterlerin belirlenmesinin seyahat acenteleri ve tur operatörlerinin etkin bir işe alım dokümanı oluşturulmasına yardımcı olacağı varsayılabilir. Yine söz konusu kriterlerin turist rehberliği eğitimi bağlamında göz önünde bulundurulması gerekliliği de eğitim uygulamalarına yönelik önemli bir katkı sağlayacaktır. Ayrıca bu çalışmada elde edilen kriterlerin bir sonraki çalışmalara ve dolayısıyla alanyazına da katkı sağlayacağı varsayılmaktadır.

\section{KAYNAKÇA}

Ahipaşaoğlu, S. (1997). Seyahat İşletmelerinde Tur Planlaması Yönetimi ve Rehberliğin Meslek Olarak Seçilmesinin Nedenleri Üzerine Bir Uygulama. Ankara: Varol Matbaası.

Akova, O., Sarışık, M. ve Akbaba, A. (2007). Seyahat Acentelerinde İşgören Bulma ve İşgören Seçme Yöntemlerine Yönelik Bir Araştırma, Karamanoğlu Mehmetbey Üniversitesi Sosyal ve Ekonomik Araştırmalar Dergisi, 3 (2): 275296.

Ap, J. veWong, K. F. (2001), Case Study on Tour Guiding: Professionalism, Issues and Problems, Tourism Management, 22 (5): 551-563.

Balta, S. (2017). Rehberlikte Kişisel Gelişim ve Paydaş İlişkileri. İçinde Ö. Güzel, V. Altıntaş, İ. Sahin (Editörler), Turist Rehberliği Araştırmaları: Öngörüler ve Uygulamalar (ss. 127-138). Ankara: Detay Yayıncilık.

Black, R. ve King, B. (2002). Human Resource Development in Remote Island Communities: An Evaluation of Tour-Guide Training in Vanuatu, International Journal of Tourism Research, 4 (2): 103-17.

Bölat, B., Kuzucu, A. (2006). Çok Amaçlı Karar Verme Problemlerine Etkileşimli Bir Yaklaşım, İTü Dergisi, 5 (1): 114-126.

Cohen, E. (1985). The Tourist Guide: The Origins, Structure and Dynamics of a Role, Annals of Tourism Research, 12 (1): 5-29.

Çimrin, H. (1995). Turizm ve Turist Rehberliğinin ABC'si. Antalya: Akdeniz Kitabevi.

Dahles, H. (2002). The Politics of Tour Guiding Image Management in Endonesia, Annals of Tourism Research, 29 (3): 783-800.

Değirmencioğlu, Ö. (1997). Ülkesel Profesyonel Turist Rehberliği Mesleğinde Yeni Gelişmelerin İzlenebilirliği, Türkiye'de Turizmin Gelişmesinde Turist Rehberlerinin Rolï. Hafta Sonu Semineri IV (ss. 211-223). Nevşehir: Erciyes Üniversitesi, Nevşehir Turizm İşletmeciliği ve Otelcilik Yüksekokulu.

Demirkol, Ş. ve Ekmekçi, İ. (2005). Paket Turların Sürdürülebilirliğinde Turist Rehberlerine Etik Bir Bakış, IV. Geleneksel Turizm Paneli (ss.59-83). Sakarya: Sakarya Üniversitesi İIBF Turizm İşletmeciliği Bölümü.

Forman, E. ve Selly, M. A. (2011). Decisons by Objectives: How to Convince Others That Your Are Right. Singapur: World Scientific Publishing.

Gündüz, S. (2002). Turist Rehberliği Eğitimi ve Üniversitelerle Turizm Bakanlığı Arasındaki Koordinasyona Yönelik Bir Model Önerisi, Turizm Eğitimi Konferansı - Workshop (ss. 243-256). Turizm Bakanlığı, Turizm Eğitim Genel Müdürlüğü. 
Güzel, F. Ö., Atilla Gök, G. ve Büyüker İșler, D. (2013). Duygusal Emek ve İşten Ayrılma Niyeti İlişkisi: Turist Rehberleri Üzerinde Bir Araştırma, Seyahat ve Otel Işsletmeciliğ̀i Dergisi, 10 (3): 107-122.

Hiore, T. (2010). Competence Model and Elements Required for Tour Guides, Kyushu Communication Studies, 8: 21-39

Huang, S. (2010). A Revised Importance-Performance Analysis of Tour Guide Performance in China, Tourism Analysis, 15 (2): 227-241.

Huang, S., Hsu, C.H.C. ve Chan, A. (2010). Tour Guide Performance and Tourist Satisfaction: A Study of The Package Tours in Shanghai, Journal of Hospitality and Tourism Research, 34 (1): 3-33.

Ji, P., Zhang, H. Y. ve Wang, J. Q. (2016). A Projection-Based TODIM Method Under Multi-Valued Neutrosophic Environments and Its Application in Personnel Selection, Neural Computing and Applications, 29 (1): 221-234.

Köroğlu, Ö. ve Güdübulak, Ö. (2017). Rehberlikte Sertifikasyon, Kalifikasyon ve Uzmanlaşma. İçinde Ö. Güzel, V. Altıntaş, İ. Sahin (Editörler), Turist Rehberliği Araştırmaları: Öngörüler ve Uygulamalar (ss. 49-76). Ankara: Detay Yayıncilık.

Köroğlu, Ö. ve Merter, B. (2012). Seyahat Acentelerinin Turist Rehberlerini Seçme ve İşe Alma Sürecindeki Eğilimlerini Belirlemeye Yönelik Bir Araştırma, Mustafa Kemal Üniversitesi Sosyal Bilimler Enstitüsü Dergisi, 20 (9): 213-238.

Kuruüzüm, A. ve Atsan, N. (2001). Analitik Hiyerarşi Yöntemi ve İşletmecilik Alanındaki Uygulamaları, Akdeniz İ̈BF Dergisi, 1 (1): 83-105.

Kwiesielewicz, M. ve Van Uden, E. (2004). Inconsistent and Contradictory Judgements in Pairwise Comparison Method in the AHP, Computers \& Operations Research, 31 (5): 713-719.

Leclerc, D. ve Martin, J. N. (2004). Tour Guide Communication Competence: French, German and American Tourists' Perceptions, International Journal of Intercultural Relations, 28 (3-4): 181-200.

Matin, H. Z., Fathi, M. R., Zarchi, M. K. ve Azizollahi, S. (2015). The Application of Fuzzy TOPSIS Approach to Personnel Selection for Padir Company, Iran, Journal of Management Research, 3 (2): 1-14.

Örücü, E. (2002). Turizm İșletmelerinde Orta ve Üst Kademe Yöneticilerin İşgören Seçme ve Değerlendirme Sürecindeki Eğilimleri: Marmaris ve Çevresindeki Üç Yıldızlı İşletmeler Örneği, Dokuz Eylül Üniversitesi İ.̇̇.B.F. Dergisi, 17 (2): 119-132.
Özdemir, E. ve Akpınar, A. T. (2002). Konaklama İşletmelerinde İnsan Kaynakları Yönetimi Çerçevesinde Alanya'daki Otel ve Tatil Köylerinde İnsan Kaynakları Profili, Kocaeli Üniversitesi Sosyal Bilimler Enstitüsü Dergisi, 3 (2): 85-105.

Profesyonel Turist Rehberi Ulusal Meslek Standardı. (2010), http://myk.gov.tr/index.php/component/msd/index. php?dl=msdupload/114 1380013222-profesyonelturst_rehber_standart.pdf, Erişim tarihi: 10 Mayis 2017.

Saaty, L. T. (1980). The Analytic Hierarchy Process. ABD: McGraw-Hill Companies.

Sabuncuoğlu, Z. (2009). İnsan Kaynakları Yönetimi Uygulama Örnekleriyle. Bursa: Furkan Ofset.

Stanujkic, D., Djordjevic, B. ve Karabasevic, D. (2012). Selection of Candidates in the Process of Recruitment and Selection of Personnel Based on The Swara and Aras Methods, Quaestus, 7: 53-64.

Şimşek, A., Çatır, O. ve Ömürbek, N. (2014). Turizm Sektöründe Bulanık Analitik Hiyerarşi Süreci ile Personel Seçimi, Uludağ Üniversitesi İiBF Dergisi, 33 (2): 147-169.

Turist Rehberliği Meslek Kanunu, http://www.resmigazete.gov. trleskiler/2012/06/20120622-2.htm, Erişim tarihi: 4 Şubat 2018.

Urosevic S, Stanujkic, D., Karabasevic, D. ve Maksimovic, M. (2017). An Approach to Personnel Selection in The Tourism Industry Based On The Swara and the Waspas,Economic Computation and Economic Cybernetics Studies and Research, Issue, 1 (51): 75-88.

Vargas, L. G. (1990). An Overview of The Analytic Hiyerarchy Process and Its Applications, European Journal of Operational Research, 48 (1): 2-8.

Weiler, B. ve Ham, S. H. (2002). Tour Guide Training: A Model for Sustainable Capacity Building in Developing Countries, Journal of Sustainable Tourism, 10 (1): 52-69.

Werther, W. B. ve Davis, K. (1993). Human Resources and Personnel Management. ABD: McGraw Hill.

Wong, A. (2001). Satisfaction With Local Tour Guides in Hong Kong, Pacific Tourism Review, 5 (1): 59-67.

Wong, J.Y. ve Lee, W.H. (2012). Leadership Through Service: An Exploratory Study of The Leadership Styles of Tour Leaders, Tourism Management, 33 (5): 1112-1121.

Zhang, H. ve Chow, Q. I. (2004). Application of ImportancePerformance Model in Tour Guides' Performance: Evidence From Mainland Chinese Outbound Visitors in Hong Kong, Tourism Management, 25 (1): 81-91.

Zhang, S. F. ve Liu, S. Y. (2011). A GRA-Based İntuitionistic Fuzzy Multi-Criteria Group Decision Making Method for Personnel Selection, Expert Systems with Applications, 38 (9): 11401-11405. 


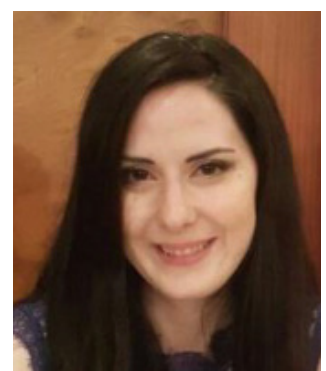

\section{Burcu ILGAZ YILDIRIM}

Lisans derecesini Gazi Üniversitesi, Ticaret ve Turizm Eğitim Fakültesi, Seyahat İşletmeciliği ve Turizm Rehberliği Öğretmenliği Bölümü’nden aldı (2008). Akdeniz Üniversitesi, Turizm İşletmeciliği ve Otelcilik Ana Bilim Dalı’nda yüksek lisansını tamamladı (2011). Iğdır Üniversitesi, Iğdır Meslek Yüksekokulu, Turizm ve Otel İ̧̧letmeciliği Bölümü’nde Öğretim Görevlisi olarak ders vermeye başladı (2011). Akdeniz Üniversitesi, Turizm İşletmeciliği ve Otelcilik Ana Bilim Dalı́ndan doktora derecesi aldı (2014). Iğdır Üniversitesi İktisadi ve İdari Bilimler Fakültesi, İşletme Bölümü'ne Yrd. Doç. Dr. olarak atandı (2014). Akdeniz Üniversitesi, Manavgat Meslek Yüksekokulu, Turizm ve Seyahat Hizmetleri Programı'nda Yrd. Doç. Dr. olarak göreve başladı (2015). Halen Akdeniz Üniversitesi Manavgat Meslek Yüksekokulu’nda görev yapmaktadır. Temel çalışma alanları, turizm İşletmeciliği ve turizm rehberliğidir.

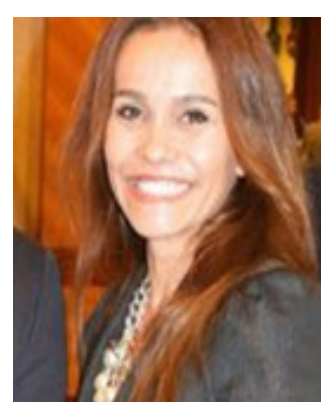

\section{Özlem GÜZEL}

Lisans derecesini Erciyes Üniversitesi, Nevşehir Turizm ve Otel Işletmeciliği Yüksekokulu, Turist Rehberliği Bölümü'nden aldı (2004). Balıkesir Üniversitesi, Turizm ve Otel İ̧̧letmeciliği Ana Bilim Dalı'nda yüksek lisansını tamamladı (2007). Incoming hizmeti veren seyahat acentelerin da turist rehberliği ve tur operasyonunda görev alarak sektör deneyimi edindikten sonra Muğla Sıtkı Koçman Üniversitesi Turizm ve Seyahat İşletmeciliği Bölümü’nde Öğretim Görevlisi olarak ders vermeye başladı (2007). Süleyman Demirel Üniversitesi, İşletme Ana Bilim Dalı'nda deneyim pazarlaması üzerine verdiği doktora teziyle doktorasını tamamladı (2012). Akdeniz Üniversitesi Turizm Fakültesi'nde Öğretim Üyesi olarak göreve başladı (2014). Doçent unvanını 2016 yılında alan Güzel'in ilgi alanları, turist rehberliği çalışmaları, turizm pazarlaması, turist deneyimi, sürdürülebilir turizm ve inanç turizmidir. 